\title{
THE LEVERAGE OF REGIONAL SECTOR FINANCIAL REPORT PRESENTMENT AND AVAILABILITY ON ACCOUNTABILITY WITH INTERNAL MANAGEMENT SYSTEM MODERATING VARIABLES
}

\author{
Frengky Julyanto Sibarani ${ }^{1 \rrbracket}$, Aloysius Harry Mukti ${ }^{2} \square$ (iD) \\ 1,2 Bhayangkara University, Greater Jakarta Accounting Study Program Jalan Raya Perjuangan, North Bekasi, \\ Indonesia
}
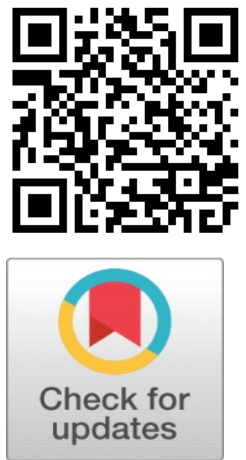

Received 27 November 2021

Accepted 09 December 2021

Published 31 January 2022

\section{CorrespondingAuthor}

Aloysius Harry Mukti,

harryaloysius2021@gmail.com

\section{DOI 10.29121/ijetmr.v9.i1.2022.1071}

Funding: This research received no specific grant from any funding agency in the public, commercial, or not-for-profit sectors.

Copyright: (C) 2022 The Author(s). This is an open access article distributed under the terms of the Creative Commons Attribution License, which permits unrestricted use, distribution, and reproduction in any medium, provided the original author and source are credited.

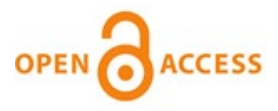

\section{ABSTRACT}

This analysis is accustomed to measuring the leverage of the presentment of financial report and the availability of financial report on the accountability of regional sector financial management with the internal management system as a moderating variable at the Office of Investment and One-Stop Services. This analysis was managed by nonprobability sampling with an accidental sampling method This analysis is represented by 91 respondents. The design used in this study is hypothesis testing using the Structural Equitation Model (SEM) - SmartPLS 3.0. The analysis of this research explain that (1) the presentment of financial report does not impact the accountability of regional sector financial management; (2) the availability of financial report has a positive leverage on the accountability of regional sector financial management; (3) the internal management system as a moderating variable has no leverage on the correlation in the middle of the presentment of financial report and the accountability of regional sector financial management; (4).

Keywords: Presentment of Financial Report, Availability of Financial Report, Accountability of Regional Sector Financial Management, Internal Management System

\section{INTRODUCTION}

The implementation of good governance is carried out by local governments as a form of realizing the aspirations of the community by following the principles of good management including the principles of openness, fairness, participation, and accountability, therefore one of the efforts to develop good governance is by increasing the accountability of regional sector financial management. Accountability is generally understood as a form of accountability related to public administration. From the Regulation of the Domestic Minister of Home Affairs Regulation Number 13 of (2006) Regarding Guidelines for Regional sector financial Management, Article 4 paragraph 1 states that regional sector finances are managed in an orderly manner, complying with laws and regulations, leveraging, efficient, economical, transparent, and responsible with due regard to the principles of justice, compliance, and benefits for the community. The government can carry out this responsibility by submitting accountability in the form of financial report. In accordance with Law Number 23 of 2014 regarding. regarding regional sector Government one of the objectives of regional sector government is to increase

\footnotetext{
How to cite this article (APA): Sibarani, F. J., and Mukti, A. H. (2022). The Leverage of Regional Sector Financial Report 
the efficiency and leverage of regional sector government administration. So that real efforts to realize transparency and accountability in government financial management, both the central government and local governments is to submit an accountability report in the form of fair and quality financial report. To find out whether the financial report prepared and presented by local governments have been properly disclosed and of good quality, the Supreme Audit Agency (BPK) will examine the financial report that have been presented annually. The occurrence that can be discovered and considered in the current development of the public sector is the enlarging demand for the implementation of public accountability by public sector organizations Mardiasmo (2018):26). By presenting good and correct regional sector financial report and fulfilling the characteristics of financial report, this will increase the accountability of regional sector financial management. In accordance with the State Financial Auditing Standards (SPKN), in examining the Bekasi Regency Government's Financial Report, BPK considers the Bekasi Regency Government's internal management system to determine audit procedures with the intention of expressing an opinion on the financial report and is not intended to provide assurance on the management system internals. The Bekasi Regency Government in the Budget Realization Report for the year ended December 31, 2018, presents the realization of regional sector Retribution Revenues of Rp. $160,509,553,792.00$, of which the realization of Building Construction Permits (IMB) of Rp. 102,485,021,384.00. The IMB levy is managed by the One Stop Service and Investment Service (DPMPTSP). The analysis of the search, confirmation, analysis, and field inspection found several problems related to the management and administration of IMB Retribution with the following details Supreme Audit Agency of the Republic of Indonesia (2018):

1) There are provisions in the Standard Operating Procedure (SOP) for the implementation of licensing services that have not been implemented,

2) There are weaknesses in the established SOPs,

3) The recording of IMB Retribution Revenue receipts by the DPMPTSP Revenue Treasurer is not carried out adequately,

4) Inadequate SKR administration,

5) Payment of SKR IMB is not orderly, and

6) Provisions in the IMB that are not carried out properly.

The BPK emphasizes the notes on the Bekasi Regency government's financial report which state that in 2018 there was a building permit retribution income of Rp. 102.48 billion, which in its management and implementation was not adequate. leverage because of the discovery of problems in its management, thus creating the risk of errors in the determination of IMB levies and the realization of their income. Therefore, a comprehensive improvement is needed with the preparation of an integrated system. BPK's opinion has not been changed in this regard (BPK, 2018). In an effort to fulfil the mandate of Law Number 15 of (2004) Regarding the Audit of State Financial Management and Responsibility, BPK submits an Audit Result Report (LHP) on the 2018 Bekasi Regency Government Financial Report, namely an examination of the financial report aimed at providing an opinion on the financial report. In examining the Financial Report, BPK revealed that there were problems related to the internal management system and compliance with laws and regulations. A well-implemented internal management system in a government institution will result in more transparent financial report, because the 
implementation of a good internal management system will ensure the reliability of financial report and financial data that can be accounted for. Sari (2017:575) in Rahma (2018) states that the better the internal management system applied to a government agency, the more transparent financial report will be, because implementing a good internal management system will ensure the reliability of financial report and financial data. Mulyanto et al. (2021) through research results also supports this statement which in this study the internal management system variable strengthens the influence of the presentment of regional sector financial report and the availability of regional sector finance on the accountability of regional sector financial management. From the phenomena that occur and the various results of previous studies, the researchers aim to conduct further research. In this study, a moderating variable is added, namely the internal management system with the emergence of the phenomenon that financial report cannot be accessed through the official website of the Bekasi Regency Government and the quality of the presentment of financial report is still low and public accountability has not been realized as indicated by the use of inadequate financial data and information. Further, the importance of this research lies in the analysis regarding public accountability.

\section{HYPOTHESES DEVELOPMENT}

\section{The Leverage of Financial Statement Presentment on Regional sector financial Management Accountability}

The presentment of financial report is an important matter in regional sector accountability. Local governments that act as public servants are expected to be able to present and convey financial information properly. The presentment made by the regions must comply with the applicable accounting standard regulations by taking into account the qualitative characteristics of financial report Mulyanto et al. (2021), Because in creating public sector accountability several components are needed and financial report are important components, it is proven that in the process of creating accountability for regional Sector financial management it is necessary to present quality financial report. According to research conducted by Miftahul (2017) shows that the availability of financial report and the presentment of financial report has a positive leverage on the accountability of regional sector financial management. These results are parallel with research conducted by Fikrian (2017) which concludes that the presentment of the financial report has positive leverage on the accountability of regional sector financial management. From the analysis of several previous studies, the following hypotheses can be formulated:

H1: The presentment of financial report has a positive leverage on the accountability of regional sector financial management.

The Leverage of Availability of Financial Report on Accountability of Regional sector financial Management

The availability of regional sector financial report is the ability of local governments to provide access to financial information. finance. According to Mulyanto et al. (2021) Accountability is a process of accountability from the first stage of planning to supervision of regional sector financial report, if the ease of accessing regional sector financial report is met. In this case, the process of 
transparency of regional sector financial report that is increasingly open and clear to the public appears, if this is done, the accountability or accountability of regional sector financial management will be of higher quality and better. From research conducted by Fikrian (2017) give the statement that the availability of financial report has a positive leverage on regional sector financial Management Accountability, then Ho is rejected, and Ha is accepted, these results are supported by research conducted by Nurlaili (2016) that the presentment of regional sector financial report impacts the accountability of regional sector financial management. The test results found significant results because the better the presentment of regional sector financial report, the clearer the local government financial reporting will be because all transactions are carried out in accordance with existing regulations and are presented completely and honestly, the report financial transparency and the realization of regional sector financial management accountability. On this basis, the hypothesis can be formulated as follows:

H2: Availability of financial report has a positive leverage on accountability for regional sector financial management.

\section{Internal Management System Moderates the Leverage of Financial Statement Presentment on Regional sector financial Management Accountability.}

Reeve et al (2013:387) in Rahma (2018) defines internal management broadly as procedures used by companies to protect company assets and provide accurate information and comply with applicable laws and regulations. Quality financial report require good internal management or internal management to demonstrate the realization of good accountability. whether regional sector financial management activities are in accordance with applicable regulations and are in favour of the public interest can be monitored by the internal management system. From research conducted by Mulyanto et al. (2021) give statement that the government's internal management system strengthens the presentment of regional sector financial report to the accountability of regional sector financial management is accepted, this is parallel with research conducted by Rahma (2018)which states that the internal management system moderates or strengthens the influence of the presentment of financial report on the accountability of Gowa Regency's regional sector financial management. On this basis, the hypothesis can be formulated as follows:

H3: The internal management system positively moderates the influence of the presentment of financial report on the liability of regional sector financial management.

\section{Internal Management System Moderates the Leverage of Availability of Financial Report on Accountability of Regional sector financial Management}

The internal management system is a monitoring process that is carried out continuously in order to oversee the running of local government. According to Mulyanto et al. (2021) Availability is the provision of access to provide information to the public at large, if the local government always provides easy access for the public to obtain regional sector financial report through media such as newspapers, magazines, radio, television stations, and websites, then the 
responsibility or accountability of management regional sector finances are becoming more qualified. Therefore, the management of the publication of financial report is very much needed by every agency because it can increase accountability through the availability of financial report with a note that every published financial report has rules for its use. This statement is in accordance with research conducted by Rahma (2018) which suggests that the analysis of the study prove that internal management moderates the leverage of availability of financial report on the accountability of regional financial management in Gowa Regency. On this basis, the hypothesis can be formulated as follows: H4: The internal management system positively moderates the leverage of availability financial report on regional financial management accountability.

\section{RESEARCH METHODS}

The method used in this research is quantitative research because the data that will be used to analyse the correlation in the middle of variables is expressed in numbers with the type of correlation research (associative), correlation research (associative) aims to determine the correlation or influence in the middle of 2 or more variables. Sugiyono (2012). The construction of correlations and influences in the middle of variables must be from theory. This research is included in the Causal Associative Research group, namely research that aims to determine the leverage in the middle of variables. The data used in this study is primary data with data collection techniques carried out by providing research questionnaires to be filled out by respondents. The population in this study were employees of the Office of Investment and One Stop Integrated Services, Bekasi Regency with a population of 187 employees. The data used in this study is primary data with data collection techniques carried out by providing research questionnaires to be filled out by respondents using accidental sampling.

\subsection{VARIABLE OPERATION}

Presentment of Financial Report (X1) Mahmudi (2016):106) states that financial report prepared by the government are required to present information fairly and fully disclose in accordance with existing regulations and requirements so that the quality of the financial report presented can meet user expectations. The quality of financial reporting is intended to increase its credibility and to achieve transparency and accountability in the financial management of local government Fikrian (2017). The measurement of financial statement presentment variables adopts four main qualitative characteristics according to Mahmudi (2016):106) that is:

1) understandable,

2) relevant, reliable and

3) can be compared

\begin{tabular}{|cccccc}
\hline Influence & $\begin{array}{c}\text { Original Sample } \\
(\mathbf{0})\end{array}$ & $\begin{array}{c}\text { Sample Mean } \\
(\mathrm{M})\end{array}$ & $\begin{array}{c}\text { Standard } \\
\text { Deviation } \\
\text { (STDEV) }\end{array}$ & $\begin{array}{c}\text { T } \\
\text { Statistics }\end{array}$ & $\begin{array}{c}\mathbf{P} \\
\text { Values }\end{array}$ \\
\hline PLK> & 0.055 & 0.076 & 0.072 & 0.769 & 0.442 \\
APKD & & & & & \\
\hline
\end{tabular}




\section{Availability of Financial Report (X2)}

In the Big Indonesian Dictionary (KBBI) availability has the meaning of things that can be used as access or things that can be linked. Information regarding accountable financial report can be easily accessed by the wider community with the availability of financial report. In increasing the availability of regional sector financial report with the intent and purpose that the information submitted by regional sector governments in regional sector financial report can implement the principles of transparency and accountability by fulfilling the following: Miftahul (2017). Measurement of the availability of financial report using indicators in Miftahul's research (2017) which explains the indicator variable can be measured by three indicators, including:

1) Openness,

2) Accessible, and

3) convenience.

\section{Internal Management System (M)}

It should be known that the internal management system is an integral process for actions taken constantly by all management levels to provide adequate assurance on the achievement of organizational goals through leveraging and efficient activities, reliability of the financial reports, safeguarding state assets, and compliance with laws and regulations. Apart from that, Mahmudi (2016) also explained that the internal management system provides adequate guarantees, not absolute guarantees, because it is very strenuous and expensive to assemble a perfect system, therefore the internal management system must be checked, evaluated, tested, developed, and improved. Measurement of internal management system variables adopting indicators in Mahmudi's research (2016) that there are four indicators in the internal management system, including:

1) management environment,

2) risk assessment,

3) Management activities, and

4) Information and communication

\section{Regional sector financial Management Accountability (Y)}

Accountability is the realization of the obligation of the party or organizational unit to account for the implementation, management of resources and management of policies entrusted to him in terms of achieving the goals that have been set through the media of periodic accountability. Fikrian (2017). While public accountability is the obligation of the holder of the trust to provide accountability, present, report and disclose all activities that are their responsibility to the party giving the mandate who has the right and authority to ask for such accountability. Mardiasmo (2018):20). The indicators in this study adopted the research of Rahma (2018) among others:

1) planning,

2) Implementation, 

3) accountability,
4) Supervision, and
5) Reporting.

\section{RESULTS AND DISCUSSION}

\section{Results of the Measurement Model (Outer Model)}

In evaluating the outer model in PLS, there are three standards, one of which is looking at Convergent Validity while for the other two standards, namely Discriminant Validity in the form of the square root of average variance extracted (AVE) and Composite Reliability. For the Convergent validity of the measurement model with reflexive indicators, it is assessed from the correlation in the middle of item scores/component scores estimated with PLS software Ramdhani (2018), Ghozali (2006): 24) assessed that the loading factor measurement scale of 0.5 to 0.6 is considered adequate for research in the early stages of development. In the next discussion, it will be discussed about the correlation of each independent variable and the dependent variable as well as the indirect correlation in the middle of the independent variable and the dependent variable with the moderating variable.

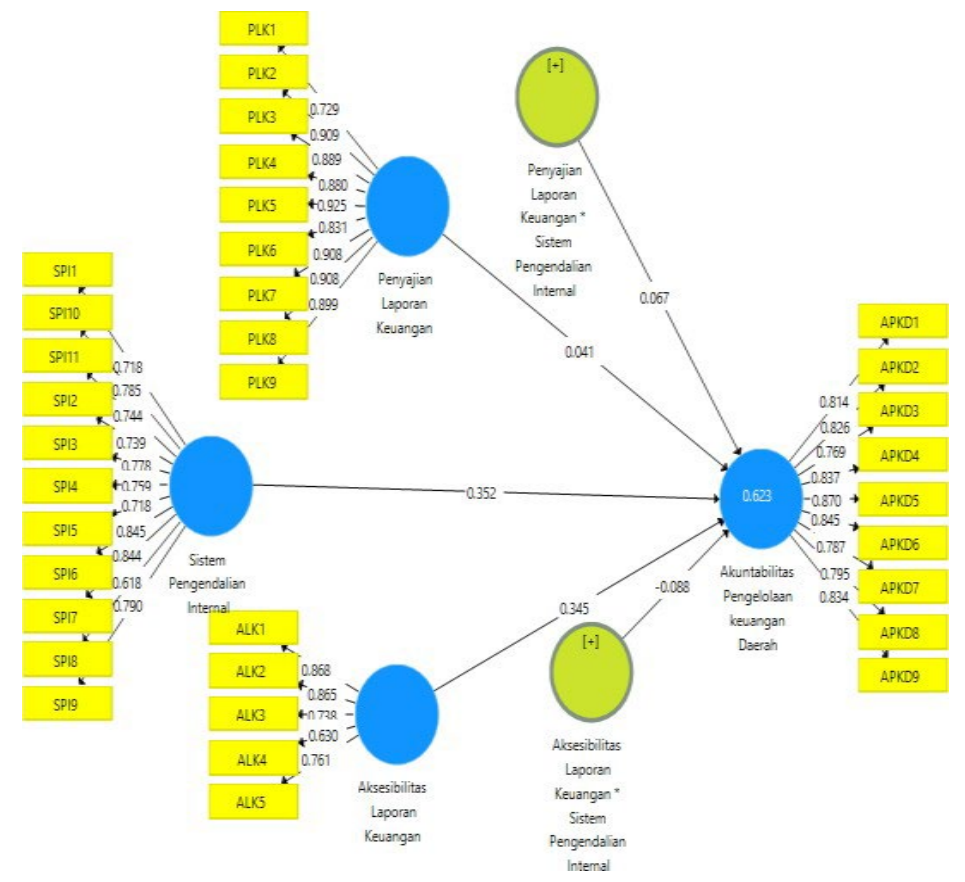

Figure 1 Full Model Structure

\section{Convergent Validity}

The analysis of processing using Smart PLS where the outer loadings value of the variable indicators of Financial Statement Presentment, Financial Report Availability, Regional sector financial Management Accountability, and Internal Management Systems, there are no indicators that have a loading factor value $<0.6$ or the correlation value in the middle of the construct and the variable has met convergent validity because it is above the loading factor value of 0.6 


\section{Composite Reliability}

In general, the value of composite reliability that can be used is at least 0.6 or more with a Cronbach's alpha score above 0.7 , it can be concluded that the reliability of this instrument is statistically reliable.

\section{Measurement Model Test Results (Inner Model)}

The inner model specifies the correlation in the middle of latent constructs with each other. The inner model can be evaluated by looking at the stability of the estimate which is assessed using statistical tests seen through the bootstrapping procedure. In assessing the model with PLS, it begins by looking at the R-square for each dependent latent variable. R-Square is a measure of the proportion of variation in the value of the impacted variable (independent variable) which can be explained by the influencing variable (dependent variable) to predict whether the model is good/bad. R-Squares value of 0.75 is said to be strong, 0.50 is said to be moderate and 0.25 is said to be weak. Table 3 is the result of R-square estimation using smart PLS Professional Editions

\begin{tabular}{|ccc|}
\hline Table $\mathbf{1}$ Value of R-Square & & \\
\hline Variable & R Square & R Square Adjusted \\
\hline Regional sector financial & 0.615 & 0.593 \\
\hline Management Accountability & & \\
\hline
\end{tabular}

From the data presented in Table 3 above, it can be seen that the adjusted Rsquare value of the regional sector financial management liability variable $(\mathrm{Y})$ is 0.593 (59.3\%). moderate. This shows that the variables of Financial Statement Presentment and Availability of Financial Report impact the regional sector financial Management Accountability variable by 59.3\% or there are still $40.7 \%$ of other variables that have not been studied in this study.

\section{Hypothesis test Hypothesis 1}

\begin{tabular}{|cccccc|}
\hline \multicolumn{3}{|c|}{ Table 2 Testing and Discussion of Hypothesis $\mathbf{1}$ Direct Leverages In the middle of Variables } \\
\hline Influence & $\begin{array}{c}\text { Original } \\
\text { Sample }(0)\end{array}$ & $\begin{array}{c}\text { Sample Mean } \\
\text { (M) }\end{array}$ & $\begin{array}{c}\text { Standard Deviation } \\
\text { (STDEV) }\end{array}$ & $\begin{array}{c}\mathbf{T} \\
\text { Statistics }\end{array}$ & $\begin{array}{c}\mathbf{P} \\
\text { Values }\end{array}$ \\
\hline PLK> & 0.055 & 0.076 & 0.072 & 0.769 & 0.442 \\
\hline APKD & & & & & \\
\hline
\end{tabular}

\section{Hypothesis 2}

Table 3 Testing and Discussion of Hypothesis 2 Direct Leverages In the middle of Variables

\begin{tabular}{|cccccc|}
\hline Influence & $\begin{array}{c}\text { Original } \\
\text { Sample (0) }\end{array}$ & $\begin{array}{c}\text { Sample } \\
\text { Mean (M) }\end{array}$ & $\begin{array}{c}\text { Standard Deviation } \\
\text { (STDEV) }\end{array}$ & T Statistics & P Values \\
\hline $\begin{array}{l}\text { ALK> } \\
\text { APKD }\end{array}$ & 0.342 & 0.333 & 0.103 & 3,312 & 0.001 \\
\hline
\end{tabular}

The outcome of analysis the second hypothesis show the correlation in the middle of Financial Report Availability and Regional sector financial Management 
Accountability as seen in the table showing the original value (0) is 0.342 with a $\mathrm{T}$ statistic of 3.312. This value is greater than the value of $t$ table (1.960). So that it can be interpreted that the correlation in the middle of Financial Report Availability has a positive leverage on regional sector Financial Management Liability.

\section{Hypothesis 3}

\begin{tabular}{|c|c|c|c|c|c|}
\hline Influence & $\begin{array}{c}\text { Original } \\
\text { Sample (0) }\end{array}$ & $\begin{array}{l}\text { Sample Mean } \\
\text { (M) }\end{array}$ & $\begin{array}{c}\text { Standard Deviation } \\
\text { (STDE V) }\end{array}$ & T Statistics & P Values \\
\hline PLK* SPI & 0.067 & 0.059 & 0.098 & 0.684 & 0.495 \\
\hline
\end{tabular}

The outcome of analysis the third hypothesis show the correlation in the middle of Financial Statement Presentment on Regional sector financial Management Accountability with the Internal Management System as a Moderation variable as shown in the table showing the original value $(0)$ is 0.067 with a T statistic of 0.684 . this value is smaller than the value of $t$ table (1.960). So that it can be interpreted that the Internal Management System does not moderate the influence of Financial Statement Presentment on Regional sector financial Management Accountability.

\section{Hypothesis 4}

\begin{tabular}{|c|c|c|c|c|c|}
\hline Influence & $\begin{array}{c}\text { Original } \\
\text { Sample (0) }\end{array}$ & $\begin{array}{c}\text { Sample Mean } \\
\text { (M) }\end{array}$ & $\begin{array}{c}\text { Standard Deviation } \\
\text { (STDE V) }\end{array}$ & T Statistics & P Values \\
\hline ALK* SPI & -0.102 & -0.101 & 0.052 & 1,969 & 0.049 \\
\hline
\end{tabular}

The outcome of analysis the third hypothesis show the correlation in the middle of Financial Report Availability and Regional sector financial Management Accountability with the Internal Management System as a Moderation variable as shown in the table showing the original value (0) is -0.102 with a T statistic of 1.969 . the value is greater than the value of $t$ table (1.960). Feasible to interpret that the Internal Management System moderates the negative leverage of Financial Report Availability on Regional sector financial Management Accountability. Discussion

\section{Hypothesis 1 (Direct leverage of presentment of financial report on accountability of regional sector financial managers)}

From the analysis of hypothesis testing and discussion of data that has been carried out by the author, what is obtained from the analysis of the study is that the Presentment of Financial Report does not impact the Accountability of Regional sector financial Management. The analysis of this study is parallel. The presentment of financial report in the DPMPTSP have the possibility to not adequate and can be seen from the existence of several problems in the implementation related to the management and administration of IMB retribution. (Financial Audit Board of the Republic of Indonesia, 2018) BPK emphasizes the notes on the Bekasi Regency government's financial report which state that in 2018 there was a building permit retribution income of Rp. 102.48 billion, which in its management and implementation was not sufficient, thus creating a risk of error in the determination 
of the IMB levy and the realization of its income. therefore, the accountability of regional sector financial management cannot be categorized as accountable. The analysis of testing the first hypothesis is parallel with the analysis of research conducted by Sari Pujiana (2018) shows that the presentment of financial report does not impact the liability of regional sector financial management. This result is not parallel with the research conducted by Miftahul (2017) which shows the positive influence of the presentment of financial report on the liability of regional sector financial management. This is because the financial report produced by the agency have not been carried out properly, as evidenced by the inadequate IMB retribution report. The more complete the presentment of financial report, the faster accountability will be implemented. On the other hand, if the presentment of financial report is incomplete, it will lead to poor Regional Financial Management Accountability, thus this factor has a positive leverage. Fikrian (2017).

\section{Hypothesis 2 (Direct leverage of availability of financial report on accountability of regional sector financial managers)}

From the analysis of hypothesis testing and data discussion conducted by the author, the analysis obtained that the availability of the report has a positive leverage on the accountability of regional sector financial management. Thus, it can be applied that the higher the level of availability of financial report, the higher the level of accountability for regional sector financial management. The analysis of testing the first hypothesis is parallel with research conducted by Superdi (2017) shows that the availability of financial report has a positive leverage on the accountability of regional sector financial management. This means that the better the availability of financial report, the better the accountability of regional sector financial management. The availability of regional sector financial report is said to be good if the government can facilitate and provide convenience to the public in obtaining information about local government financial report. In addition to presenting regional sector financial report, local governments must provide convenience for users of financial report in accessing regional sector financial report, so that accountability for regional sector financial management can run well.

\section{Hypothesis 3 (Indirect leverage of financial statement presentment on the accountability of regional sector financial managers with the internal management system as a moderating variable)}

From the analysis of hypothesis testing and data discussion that has been carried out by the author, what is obtained from the research results is that the internal management system does not moderate the leverage of financial statement presentment on regional sector financial management accountability. Thus, the existence of an internal management system does not impact the level of reliability and relevance of the presentment of financial report. These results are parallel with research conducted by Yolanda (2018) which states that the internal management system does not moderate the leverage of the presentment of financial report on the accountability of regional sector financial management. However, the analysis of this study is not parallel with research conducted by Rahma (2018) which shows that the internal management system moderates the leverage of the presentment of financial report on the availability of financial report on the accountability of regional sector financial management. This happens because there is no internal 
management system regarding the presentment of financial report at the Service and this allows for misreport or presentment of financial report that are not relevant and reliable. By implementing and running an internal management system related to the presentment of financial report, it is hoped that there will be no presentment of irrelevant financial report and can increase the accountability of regional sector financial management. Hypothesis 4 (Indirect leverage of financial statement availability on accountability of regional sector financial managers with internal management system as moderating variable) From the analysis of hypothesis testing and discussion of data that has been carried out by the author, what is obtained from the research results is that the internal management system negatively moderates the leverage of availability of financial report on regional sector financial management accountability. Thus, the existence of an internal management system cannot strengthen the availability of financial report. These results are parallel with research conducted by Rahma (2018) which shows a negative influence, and the internal management system can strengthen the influence of the availability of financial report on the accountability of regional sector financial management. This is not parallel with the research conducted by Mulyanto et al. (2021) which states that the internal management system does not moderate the leverage of the presentment of financial report on the accountability of regional sector financial management. This happens because the management system implemented has not been carried out optimally by the employees of the Bekasi Regency Investment and One Stop Integrated Service Office. The internal management system has not been implemented by service employees as reflected in the analysis of the questionnaires that have been collected and it is concluded that from the statement there is the lowest score, namely the first statement of the internal management system with the statement that this service establishes standards of behaviour and policies that must be obeyed by employees. This allows for violations of procedures to be carried out by service employees, including the lack of good availability because they do not run the existing internal management system.

\section{CLOSING}

\subsection{CONCLUSION}

From the discussion above, the authors provide conclusions in this study as follows:

1) The presentment of financial report does not impact the accountability of regional sector financial management.

2) The availability of financial report has a positive leverage on the accountability of regional sector financial management.

3) The internal management system does not moderate the leverage of the presentment of financial report on the liability of regional sector financial management.

4) The internal management system moderates the negative impact of the availability of financial report on the accountability of regional sector financial management 


\subsection{IMPLICATION}

From the analysis of the analysis, discussion, and conclusions. The implications of this research are as follows:

1) For regional sector financial management accountability research, it is better for the management to start implementing an improvement in the internal management system of each existing section, especially the finance section, with periodic evaluation of the internal management system to reduce the level of errors in regional sector financial management in order to achieve an accountable office.

2) This research is expected to be of benefit to the Office of Investment and One Stop Integrated Services of Bekasi Regency that the presentment of financial report and the availability of financial report are two important things, and each have their respective roles in achieving regional sector financial management accountability. Both have a correlation with each other because they can have an impact on the Office in the management of accountable regional sector finances.

\subsection{RESEARCH LIMITATIONS} follows:

In conducting this research, the authors face several limitations of the study as

1) It is feared that the measurement process that does not confront the respondent with real conditions will cause the respondent to answer the statement normatively, so that the research results may be biased with the actual conditions that occur in the field.

2) Of the number of respondents who work at the Bekasi City Population and Civil Registration Service, only 91 are willing to fill out the questionnaire and only $39 \%$ of the respondents from the finance department are $39 \%$ of the total 91 respondents. This is due to the busyness of these employees, especially in the finance department.

3) This research only focuses on the Office of Investment and One Stop Integrated Services Office of Bekasi Regency so that further researchers can expand the research location.

\section{REFERENCES}

Center for the Study of State Financial Accountability Expertise Board of the Republic of Indonesia. (2017). Accountability \& Dynamics of Regional Financial Management.

Fikrian, H. (2017). The Influence of Financial Report Quality, Financial Statement Presentment and Financial Report Availability on Regional sector financial Management Accountability. JOMFekom, 4(1), 256-279. Retrieved from https://media.neliti.com/media/publications/1 25589-ID-analysis-impactpemekaran-area- ditinja.pdf 
Ghozali, I. (2006). Multivariate Analysis Application with PLS Program. Publishing Agency-UNDIP.

Law Number 15 of (2004). concerning Audit of State Finance Management and Responsibility.

Mahmudi. (2016). Public Sector Accounting (Revised). UII PRESS.

Mardiasmo. (2018). Public Sector Accounting (Latest). ANDI PUBLISHER.

Miftahul, Fauziyah R. (2017). The Leverage of Presentment and Availability of Regional sector financial Report on Accountability of Regional sector financial Management. Journal of Chemical Information and Modeling, 53(9), 1689-1699.

Minister of Home Affairs Regulation Number 13 of (2006) concerning Guidelines for Regional sector financial Management, 1 (2006).

Mulyanto, Budiman, NA, \& Fahmi, MN (2021). The Influence of Regional sector financial Accounting System, Presentment of Regional sector financial Report, Availability of Regional Financial Report, and Fiscal Decentralization on Accountability of Regional Financial Management With Government Internal Management System as Variable. Journal of Economic Frames, 6(1), 16-26. Retrieved from http://itbsemarang.ac.id/jbe/index.php/jbe33/ article/view/91

Nurlaili. (2016). The Influence of Financial Statement Presentment and Financial Report Availability on Financial Management Accountability in the Study Area at SKPD Bengkalis Regency. 3(1), 462-476.

Rahma Nur. (2018). Accessibility of Financial Statements and Presentation of Regional Financial Statements on Accountability of Regional Financial Management with Internal Control as Moderating Variable.

Ramdhani, D. (2018). The Role of Organisational Virtue and Public Accountability In Influencing Public Sector Performance in Regional Apparatus Organizations in Banten Province. Journal of Integrated Accounting Research, 11(2). Retrieved from https://doi.org/10.35448/jrat.v11i2.4261

Sari Pujiana, D. (2018). The Influence of Regional Financial Statement Presentation and Regional Financial Accounting System on Regional Financial Management Accountability with Accessibility of Regional Financial Reports as Moderating Variable.

Sugiyono. (2012). Quantitative, Qualitative, and R\&D Research Methods. Alphabeta Publisher.

Superdi. (2017). The Effect of Financial Statement Presentation, Accessibility and Regional Financial Accounting System on Regional Financial Management Accountability (Empirical Study on the Sijunjung Regency Regional Work Unit). JOMFekom, 4(1), 205-2019.

Supreme Audit Agency of the Republic of Indonesia (2018). Audit Result Report on the 2018 Bekasi Regency Government Financial Report.

Yolanda, S. (2018). The Influence of Regional Financial Accounting System, Presentation of Regional Financial Statements and Accessibility of Regional Financial Reports on Accountability of Regional Financial Management with Government Internal Control System as Moderating Variable. JOM FEB, Volume 1 Issue 1 (January - June 2018), 1 